Vol. 1, No. 1, 1993

\title{
ELASTOMERIC COMPOSITIONS FOR THE PRODUCTION OF RUBBER ARTIFACTS USED IN SHOE MANUFACTURING AND CIVIL CONSTRUCTION
}

\author{
José Cläudio Del Pino*, Anildo Bristoti and Märio Pinheiro \\ Departamento de Química Inorgânica, Instituto de Química \\ Universidade Federal do Rio Grande do Sul \\ Av. Bento Gonçalves 9500 \\ 91540-000 Porto Alegre, RS BRASIL
}

\section{ABSTRACT}

Sugar cane bagasse is a common byproduct of the alcohol and sugar industries. In the present work we describe the preparation of elastomejic agglomerates containing SBR [polylstyrenebutadiene) and bagasse or kaolin as inert filler. The experimental results and a series of laboratory and field tests show that the sugar cane bagasse agglomerate can be very appropriate and useful for practical applications, especially in the manufacture of shoe soles.

\section{RESUMO}

o bagaso de cana-de-ąücar é um subproduto comum da indüstria acucareira e do älcool. o presente estudo descreve a preparacão de aglomerados elastoméricos contendo SBR [polilestireno-butadienol] e bagago de cana ou caulim como carga inerte. Os resultados experimentais e uma série de ensaios de laboratório e de campo mostram que o aglomerado com bagaco de cana-de-acúcar pode ter vârias aplicacõos präticas, especialmente na fabricacão de solas de sapatos.

KEYWORDS: Sugar Cane Bagasse, Elastomeric Composites, Agglomerates.

\section{INTRODUCTION}

Sugar cane bagasse has been used in many countries of the world for the manufacturing of composite agglomerated materials employed on a large scale in buildings, furniture and means of transportation!. It is a byproduct of the sugar and alcohol industries with a chemical composition consisting mainly of lignin and cellulose2. It represents about $25 \%$ of the milled or ground sugar cane and at times there is a surplus of up to $30 \%$, since its use as fuel depends upon the energy requirements of the industrial complex $3,4,5$.

Because of its physical and chemical properties, sugar cane bagasse can be used as an inert filler for elastomeric composites employed for the manufacture of rubber artifacts in the place of kaolin and carbonates 6,7 . When added to plastifying materials such as phenolic resins, it facilitates the industrial processing of the vulcanizate and improves mechanic properties such as hardeness, resistance to abrasion and to heat 7,8 .

The purpose of this work is to use finely divided bagasse

* Author to whom correspondence should be addressed. 
mixed with phenolic resin and incorporate it into elastomers in varying proportions. The study of the physical and mechanical properties of the different rubber composites should give some clues for the possible use of some of these new materials for the production of rubber artifacts for the shoe, furniture and construction industries.

\section{MATRRIALS AND METHODS}

Sugar cane bagasse ( $S C B$ ) was ground, dried and sifted to obtain fractions that were $35 / 60$ and $60 / 100$ Mesh. These were subsequently added to SBR :elastomers of [poly(styrene-butadiene)] together with other ingredients whose composition is expressed in "parts per hundred parts of rubber" (phr). The formulations are described in Tables I and II.

TABLE I. FORMULATIONS OF RUBBER COMPOSITES.

\begin{tabular}{|c|c|c|c|}
\hline & I (phr) & II (phr) & II (phr) \\
\cline { 2 - 4 } SBR 1502 & 100,0 & 100,0 & 100,0 \\
\hline Stearic Acid & 2,0 & 2,0 & 2,0 \\
\hline Zinc Oxide & 5,0 & 5,0 & 5,0 \\
\hline Vulkanox HS & 1,0 & 1,0 & 1,0 \\
\hline Sicosil 45 & 30,0 & 30,0 & - \\
\hline $\begin{array}{c}\text { Polyethylene Glycol } \\
\text { (PEG-4000) }\end{array}$ & 3,0 & 3,0 & - \\
\hline $\begin{array}{c}\text { Mercaptobenzothiazol } \\
\text { (MBT) }\end{array}$ & 1,5 & 1,5 & 1,0 \\
\hline $\begin{array}{c}\text { Diphenylguanidine } \\
\text { (DPG) }\end{array}$ & 1,5 & 1,5 & 1,0 \\
\hline Sulfur & 2,0 & 2,0 & 2,0 \\
\hline Phenolic Resin & 5,0 & 5,0 & 20,0 \\
\hline $\begin{array}{c}\text { Sugar Cane Bagasse } \\
\text { (SCB 35/60) }\end{array}$ & - & - & 200,0 \\
\hline $\begin{array}{c}\text { Sugar Cane Bagasse } \\
\text { (SCB 60/100) }\end{array}$ & 25,0 & - & - \\
\hline Kaolin & - & 25,0 & - \\
\hline TOTAL & 176,0 & 176,0 & 332,0 \\
\hline
\end{tabular}

Samples of kaolin ( $\mathrm{pH}=6,3$ and $0,4 \%$ residue of 325 Mesh) were added to the elastomer under the same conditions as bagasse. Formulations I and II, using $25 \mathrm{phr}$ of filling and 5 phr of phenolic resin, Thor MD 278 , were intended for the manufacture of rubber artifacts for the shoe industry, since they gave better properties according to results already described 9,10 . 
Formulation III was intended for the production of new materials to be used as wood substitutes. The ingredients were homogenized in an open blender or mixer. The test samples were vulcanized at $1659 \mathrm{C}$ and their mechanical and physical properties were determined using the following tests: D 2240-75 for Hardness Shore A and D,D 412-75 for Tension at Break and Elongation, D 29777 for Hydrostatic Density, 55516 for Abrasion, 53.507 for Progressive Tear, 53.543 for Flexion and MB 26 for Tension of Flexion and the PFI Method was used for Special Abrasion. These tests have been described by ASTM/DIN. The density of the filler was determined by using a pycnometer and the determination of the volatile material was performed using the $D 1817$ method, described in the 1 iterature 11,12 .

TABLE II. CHARACTERIZATION OF FILLERS.

\begin{tabular}{|c|c|c|}
\hline Property/ Filler & Density (25 $\mathbf{C})$ & Humidity (\%) \\
\hline SCB 35/60 Mesh & 1,40 & 6,34 \\
\hline SCB 60/100 Mesh & 1,40 & 6,12 \\
\hline Kaolin 200/325 Mesh & 2,60 & 0,30 \\
\hline
\end{tabular}

Field tests were performed using rubber composites in the soles of shoes used by mailmen during their regular working schedule for 25 days. Comparisons were done between soles made from sugar cane bagasse and kaolin, fiberboard, agglomerate industrially available and elastomeric agglomerate with sugar cane bagasse.

\section{RESULTS AND DISCUSSION}

As can be seen in Table II, kaolin has a density $85 \%$ higher than sugar cane bagasse. This leads to a higher hydrostatic density and lesser efficiency in volume (bulk) in terms of material processing. This means that for the same mass of composites, one containing sugar cane bagasse and the other kaolin, that with bagasse will produce a greater number of parts.

Analysis of the results sumarized in Tables III and IV, compared to the compositions containing kaolin, indicates that the rubber compositions with sugar cane bagasse have a higher hardness and resistance to progressive tear.

on the other hand, hydrostatic density and abrasion exhibj.t lower values as does resistance to flexion. This means that rubber compositions with sugar cane bagasse have the characteristics necessary for the use in shoe soles production. The field cests showed that soles of shoes used by mailmen and made with elastomeric compositions containing sugar cane bagasse met the requirements. These results are in agreement with previous studies 
described by our group 10 and show that the biending of phenolic resins and sugar cane bagasse is satisfactory and reinforces the desired properties of the compositions.

TABIE III. MECHANICAL PROPERTIES OF RUBBER COMPOSITES.

\begin{tabular}{|c|c|c|}
\hline Property & Composition & Value Obtained \\
\hline Hardness Shore A & SCB & 75 \\
\cline { 2 - 3 } & Kaolin & 68 \\
\hline Elongetion(\%) & SCB & 520 \\
\cline { 2 - 3 } & Kaolin & 600 \\
\hline $\begin{array}{c}\text { Tension at Break } \\
(\mathrm{MPa})\end{array}$ & $\mathrm{SCB}$ & 9,3 \\
\hline $\begin{array}{c}\text { Hydrostatic Density } \\
\left(\mathrm{g} / \mathrm{cm}^{3}\right)\end{array}$ & $\mathrm{Kaolin}$ & 13,6 \\
\hline \multirow{2}{A}{$\begin{array}{c}\text { Abrasion } \\
\left(\mathrm{mm}^{3} / 40 \mathrm{~m}\right)\end{array}$} & $\mathrm{SCB}$ & 1,15 \\
\hline & $\mathrm{Kaolin}$ & 1,21 \\
\hline
\end{tabular}

TABLE IV. SPECIFIC PROPERTIES EVALUATED FOR SHOE MANUFACTURING.

\begin{tabular}{|c|c|c|c|}
\hline Test & Especification & Composition & Value Obtained \\
\hline \multirow{2}{*}{$\begin{array}{l}\text { Progressive } \\
\text { Tear }\end{array}$} & \multirow[t]{2}{*}{$8,0 \mathrm{~N} / \mathrm{mm}$} & $\mathrm{SCB}$ & $14,4 \mathrm{~N} / \mathrm{mm}$ \\
\hline & & Kaolin & $10,2 \mathrm{~N} / \mathrm{mm}$ \\
\hline \multirow[t]{2}{*}{ Flexion } & \multirow{2}{*}{$\begin{array}{c}\text { Maximum } \\
\text { Progression } 4 \mathrm{~mm}\end{array}$} & $\mathrm{SCB}$ & passes test \\
\hline & & Kaolin & passes test \\
\hline \multirow{2}{*}{$\begin{array}{c}\text { Special } \\
\text { Abrasion PFI }\end{array}$} & \multirow{2}{*}{$\begin{array}{c}\text { Parameter for } \\
\text { outdoor shoes } 0,8 \mathrm{~mm}\end{array}$} & $\mathrm{SCB}$ & $0,33 \mathrm{~mm}$ \\
\hline & & Kaolin & $0,42 \mathrm{~mm}$ \\
\hline
\end{tabular}

Ther are specific interactions at the elastomer-fillex interface such as covalent and hydrogen bonds and these are well known. The effect of vulcanizing agents such as sulfur or phenolic resins on these interactions have also been described 7,13 . These compounds, as well as the reinforcing filler tend to form cross-linking between the polymer chains. Figure 1 illustrates the relationship between the density of crosslinking or reticulation, nature of polymer and filler, and some properties of the vulcanizate 7 . 


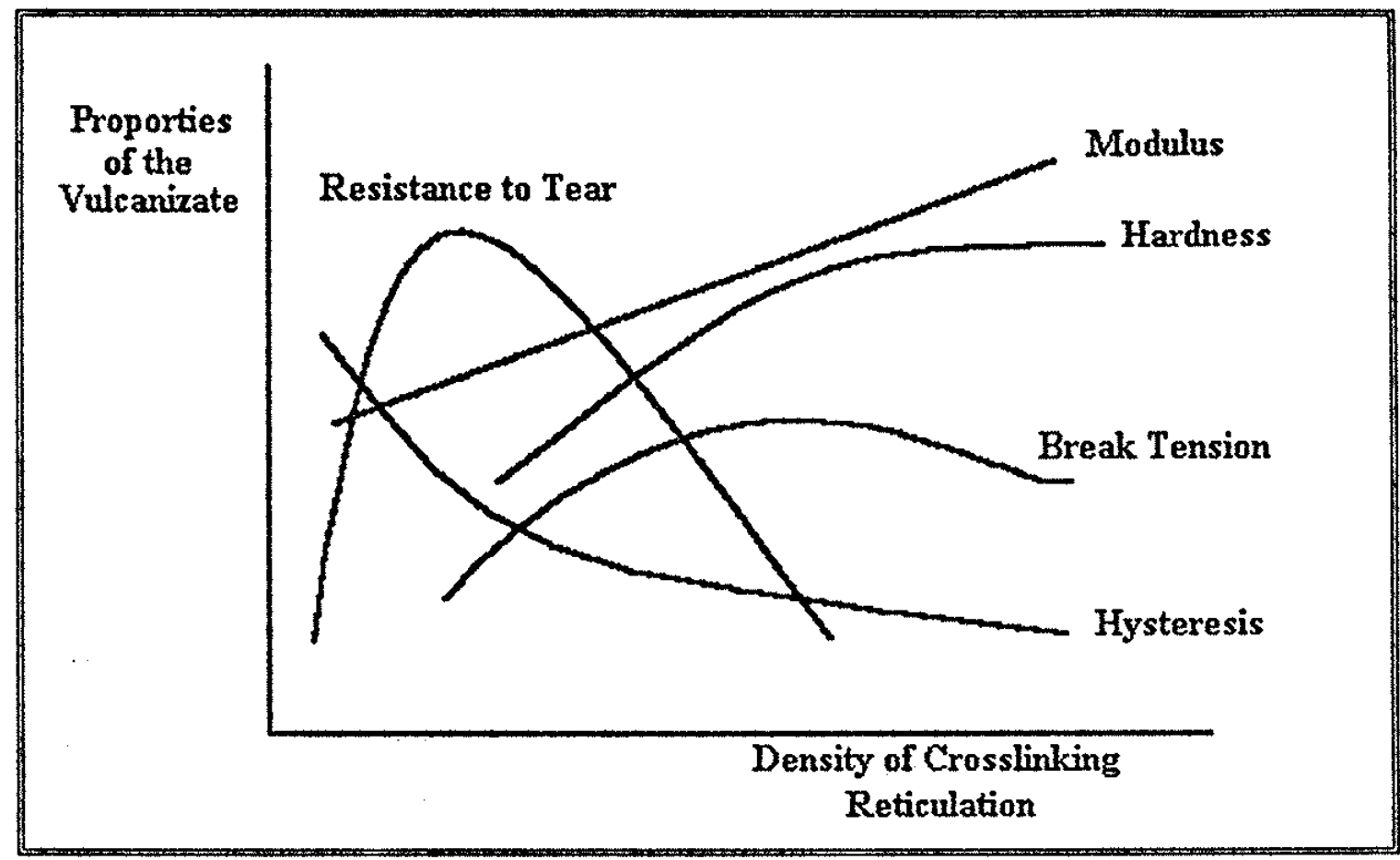

FIGURE 1. RELATIONSHIP BETWEEN PROPERTIES OF THE VULCANIZATE AND INTENSITY OF RETICULATION.

When compared to fiberboard and agglomerates commercially available, the agglomerated elastomer containing sugar cane bagasse has a higher flexibility. It deforms under a flexion tension of $1,5 \mathrm{MPa}$ without tear and it returns to the original position at the end of the test. The other materials used in this study break under the flexion tension conditions described in Table V. The elastomeric agglomerate may be cut, nailed or

TABLE V. MECHANICAL PROPERTIES OF AGGLOMERATE.

\begin{tabular}{|c|c|c|c|}
\hline Test & $\begin{array}{c}\text { Commercial } \\
\text { Fiberboard }\end{array}$ & $\begin{array}{c}\text { Commercial } \\
\text { Agglomerate }\end{array}$ & $\begin{array}{c}\text { Sugar Cane Bagasse } \\
\text { Elastomers }\end{array}$ \\
\hline $\begin{array}{c}\text { Flexion Tension } \\
(\mathrm{MPa})\end{array}$ & 6,1 & 2,0 & 1,5 \\
\hline $\begin{array}{c}\text { Hardness } \\
\text { Shore D }\end{array}$ & 60 & 60 & 40 \\
\hline
\end{tabular}

secured with screws with a performance similar to that of wood. Its hardness depends on the amount of phenolic resin and of sugar cane bagasse present in the composition and it may reach Hardness Shore 40 values similar to those of agglomerate and fiberboard. 


\section{RERERRNCES}

1. V. Nagy, Silvae Cultura Tropica et Subtropica, 5, 127-134 $(1976)$.

2. T. J. B. Menezes, "Etanol. O Combustivel do Brasil", Editora Agronômica Ceres, Ltda., São Paulo, 1980, 233 pp.

3. Sociedade de Produtores de Açūcar e $\bar{A}$ lcool-SoPRAL, "Avaliação do Bagąo de Cana-de-Aqúcar", São Paulo, $1983,101 \mathrm{pp}$.

4. M. T. Tolmasquim, "Anais IV Congresso Brasileiro de Energia", Rio de Janeiro, 1987, pp. 1159-1166.

5. J. G. Silva, G. E. Serra, J. R. Moreira and J. C. Gonçalves, Brasil Aqucareiro (Piracicaba), 6, 452-465 (1976).

6. R. O Babbit, "The Vanderbilt Rubber Handbook", R. T. Vanderbilt Company, Inc., Los Angeles, 1978, 950 pp.

7. F. R. Eirich, "Science and Technology of Rubber", Academic Press, Inc., New York, 1978, 670 pp.

8. P. 0. Powers, Rubber Chemistry and Technology, 36(5), 1558-1570 (1963).

9. J. C. Del Pino, H. R. Soares and A. Bristoti, "Anais XXVIII Congresso Brasileiro de Quimica", Porto Alegre, RS, 1988.

10. J. C. Del Pino, M. Pinheiro and E. Forte, "Anais $X X X I$ Congresso Brasileiro de Quimica", Recife, PE, 1991.

11. American Society for Testing Materials-ASTM, "Annual Book of ASTM Standards. Part 37", Philadelphia, Pa., 1979, $888 \mathrm{pp}$.

12. Superintendência da Borracha- MIC, "Poligrafos do Curso de Tecnologia dos Elastômeros", Porto Alegre, RS, 1987.

13. R. D. Deanin, "Polymer Structure, Properties and Applications", Cahners Publishing Company, Inc. Boston, Mass., USA, $1972,496 \mathrm{pp}$. 